\title{
Umberto Bresciani, Reinventing Confucianism
}

Taipei, Taipei Institute for Chinese Studies (Variétés Sinologiques New Series 90), IX + 652 pp.

Léon Vandermeersch

\section{(2) OpenEdition}

\section{Journals}

Édition électronique

URL : http://journals.openedition.org/chinaperspectives/242

DOI : 10.4000/chinaperspectives.242

ISSN : 1996-4617

Éditeur

Centre d'étude français sur la Chine contemporaine

\section{Édition imprimée}

Date de publication : 1 février 2003

ISSN : 2070-3449

Référence électronique

Léon Vandermeersch, « Umberto Bresciani, Reinventing Confucianism », China Perspectives [En ligne], 45 | january-february 2003, mis en ligne le 22 août 2006, consulté le 21 septembre 2020. URL : http:// journals.openedition.org/chinaperspectives/242 ; DOI : https://doi.org/10.4000/chinaperspectives. 242

Ce document a été généré automatiquement le 21 septembre 2020.

(C) All rights reserved 


\title{
Umberto Bresciani, Reinventing Confucianism
}

\author{
Taipei, Taipei Institute for Chinese Studies (Variétés Sinologiques New \\ Series 90), IX + 652 pp.
}

Léon Vandermeersch

1 Having represented state ideology from one end of eastern Asia to the other for two thousand years, Confucianism today is no more than a mark left on customs by this ideology. A profound mark, admittedly, but one that has been gradually fading for almost a century since the old system disappeared from China. What meaning then, can the movement that was launched hot on the heels of the May 4th Movement of 1919 and which took the name New Confucianism possibly have? The answer to this question is made clear in Umberto Bresciani's excellent book.

2 First and foremost, as the author reminds us in his introduction, New Confucianism must be distinguished not only from Song Neoconfucianism (although New Confucians feel they are more in line with thinkers of this persuasion, especially after the refocusing brought about by Wang Shouren under the Ming), but even more so from the attempt at fundamentalist restoration of Confucian ideology that was led by Kang Youwei at the beginning of the Republican era. Just as Hu Shi, a follower of American liberalism, and Chen Duxiu, a Marxist, together the promoters of New Confucianism, advocated a real revolution-but a revolution based on Chinese culture, and not a revolution that would destroy this culture using cut-and-dried westernisation, whether it be American or Soviet style. A revolution that restored the values attached to authentic Chinese culture, destroyed by the degeneration of a pseudo-Confucian tradition through anti-scientific and anti-democratic corruption. This is what is explained at great length in a very detailed text published, in English in Hong Kong on January 1 st 1958 in the magazine Democratic Tribune-firm proof of there being not the slightest affinity with Chinese chauvinism-under the founding title of A Manifesto on the Reappraisal of Chinese Culture.

3 Why did we have to wait until forty years after May 4th 1919 for this manifesto to appear? Because the early promoters of New Confucianism, while clearly asserting 
their differences with Marxism, did not dissociate themselves from the most revolutionary Chinese movement of the period between the two World Wars, i.e. the Communist Party. Liang Shuming (1893-1988), inventor of a philosophy of history as contrary to that of historical materialism as to that of traditional Chinese historiography, and Xiong Shili (1885-1968), whose ambition was to reshape Confucianism metaphysically by accentuating Buddhism, not sociologically based on the class struggle theory, were, nevertheless, both fellow travellers of the communists, and remained popular in China right up to their deaths. As for Feng Youlan (1903-82), after trying to regenerate Neoconfucianism (in the sense taken in the Yijing by the articulation of the two terms zhen-yuan (death-revival) that he used as titles for his philosophical writings) by radically reforming its methodology, in 1950 he sent Mao Zedong a confession of his full conversion to the new China.

But the establishment in mainland China of the communist regime did nevertheless provoke a reaction from the supporters of Neoconfucianism through the awareness that was to be expressed by the manifesto. On the mainland, the unconverted fellow travellers were soon to become voluntarily marginalised. Those who decided to follow the movement by breaking with communism emigrated to Hong Kong, where, on October 10th 1949, on the anniversary of the Chinese Republican revolution of 1911, Qian Mu (1895-1990) and Tang Junyi (1909-78) founded the New Asia College (Xinya shuyuan, initially called Yazhou wenshang shuyuan), which was to become the centre of second generation New Confucianism. While the first generation had displayed affinity more with socialism, the second generation responded to the antidemocratic radicalisation of Maoism by leaning much more towards liberalism, but not without keeping their distance from any political commitment. This concern for independence drove the major intellectuals of the movement to keep their own counsel in the context of the universities that gave them refuge. In Hong Kong, following the integration of New Asia College into the Chinese University founded in 1963, it was not long before Qian $\mathrm{Mu}$ withdrew, while Tang Junyi headed up an autonomous research centre. Mou Zongsan (1909-95), who had chosen Taiwan, initially dispensed his teachings at the teacher training college (Shifan shuyuan, later to become a university) that he founded himself, then, in September 1956 when he became head of the Department of Chinese at the Tunghai protestant university in Taichung, in the bimonthly lectures for a humanist club (Renwen youhui) that he organised as extracurricular activities.

5 The death of Tang Junyi in 1978 revealed, by the extent to which it was felt throughout Chinese intellectual circles in Hong Kong, Taiwan and America, the great influence attached to New Confucianism at that time. It was now supported by a third generation, which included, most importantly, in Hong Kong, Liu Shuxian (born in 1934 and a pupil of Fang Dongmei, director of the Department of Philosophy at the Chinese University from 1981), and in the US, Yu Yingshi (born in 1930 and Qian Mu's star pupil, who, like his master, preferred to avoid the New Confucianism label, even though the essence of his teachings at Princeton is very similar), Du Weiming (born in 1940 and a pupil of Mou Zongsan and Xufuguan, became a Harvard professor), and Cheng Zhongying (born in 1935 and a pupil of Fang Dongmei, who taught in Hawaii). Their ideas found increasing support among a group of same-generation young intellectuals in Taiwan, Singapore and soon, even mainland China, where the discrediting of Marxism as a result of the massive expansion of the so-called socialist market economy, New Confucianism unexpectedly appeared as a questionable, if not acceptable, alternative. In 1984, the Confucius Foundation was established at Qufu, under the leadership of the 
octogenarian Liang Shuming. In 1986, a huge research project on New Confucianism was launched in Peking. Involving 47 researchers and 16 institutions, this project would lead to, among others, the publication in 1996 of 16 volumes of anthologies of works by the most representative authors of the movement. Since then, there has been a surge in the number of international symposia on the subject, as well as an increase in research works and the republication of previously published works. A young generation of philosophers is taking positions that are no longer purely theoretical and which call for political commitment. As is the case, for example, for a pupil of Du Weiming, Jiang Qing, a Shenzhen-based researcher, in an essay entitled Political Confucianism (Zhengzhi ruxue).

6 In Chapters 3 to 15 of his book, Umberto Bresciani reviews these three generations of New Confucianism, focusing on the movement's 11 most influential figures. For each, he first presents a brief biography, followed by an analysis of their doctrine and their work, and finally, an evaluation of their ideas and influence. The systematic usage of this layout from one chapter to another, which is further emphasised by a standard typographical presentation, does make this book a bit starchy. But, this approach has the advantage of making the material very clear. This should ensure that the reader recognises the strength of such a complete firsthand account, which is evidenced by the abundance of very detailed notes and the lavishness of an excellent selective bibliography. The sixteenth and final chapter concludes by summing up the common characteristics of the thinkers examined - their belief in defending the values of true Confucianism, their sense of the spiritual dimension of the culture, their mistrust of the scientistic tendencies of contemporary science, and their attraction to East/West comparative philosophy.

7 Finally, Umberto Bresciani turns to the outlook for the future. Recognising that in its 80 year history, New Confucianism has continued to expand and to increase its audience among intellectual Chinese (a fact to which, oddly enough, Western sinology, being focused firmly on Maoism, has remained blind), he notes that this expansion is such that today, it is no longer possible to talk about a single New Confucianism for the mainland, for Taiwan, for Chinese communities in the West, even for countries in the Far East that are heavily influenced by China. What can we say if not that the prospect is taking shape that the twenty-first century might see, in an oriental Asia that has caught up with development in the West, a renaissance of a culture appropriate for the Chinese world in all its diversity? A renaissance for which, at the end of the last century, by opening the debate on Asian values, the anti-democratic powers in the region were looking to launch an early reactionary takeover bid, something at which we can hope that they remain unsuccessful. 